\title{
Going Public: Debating Matters of Concern as an Imperative for Management Scholars
}

\begin{tabular}{|r|l|}
\hline Journal: & Academy of Management Review \\
\hline Manuscript ID & AMR-2018-0016-RE.R2 \\
\hline Manuscript Type: & Review Essay-By Invitation Only \\
\hline Theoretical Perspectives: & $\begin{array}{l}\text { Practice-base (evidence based) theory, Philosophy of science and/or } \\
\text { sociology of knowledge, Strategic management process/implementation } \\
\text { strategy }\end{array}$ \\
\hline Topic Areas: & $\begin{array}{l}\text { Innovation and Creativity < Organization and Management theory, } \\
\text { Entrepreneurship and Organizational Emergence < Organization and } \\
\text { Management theory, Impact on Society < Organization and Management } \\
\text { theory }\end{array}$ \\
\hline Abstract: & $\begin{array}{l}\text { Review essay of: The Green and the Black: The Complete Story of the } \\
\text { Shale Revolution, the Fight Over Fracking, and the Future of Energy, by } \\
\text { Gary Sernovitz. New York: St. Martin's Press, 2016; and Under the } \\
\text { Surface: Fracking, Fortune, and the Fate of the Marcellus Shale, by Tom } \\
\text { Wilber. Ithaca: Cornell University Press, 2015 (updated edition). }\end{array}$ \\
\hline \multicolumn{2}{|c|}{} \\
\hline
\end{tabular}




\title{
GOING PUBLIC: DEBATING MATTERS OF CONCERN \\ AS AN IMPERATIVE FOR MANAGEMENT SCHOLARS
}

\author{
Dror Etzion \\ McGill University \\ Montreal, Canada \\ dror.etzion@mcgill.ca \\ Joel Gehman* \\ University of Alberta \\ Edmonton Canada \\ jgehman@ualberta.ca
}

August 7, 2018

\begin{abstract}
Accepted for publication in the Academy of Management Review
\end{abstract}

\footnotetext{
${ }^{*}$ Corresponding author. Authors contributed equally and are listed alphabetically. A special thanks to Jean Bartunek for her patient, detailed, and engaged editorial guidance. We thank Bandita Deka Kalita for her research assistance. Financial support provided in part by the Canada First Excellence in Research Fund and the Social Sciences and Humanities Research Council of Canada.
} 


\section{GOING PUBLIC: DEBATING MATTERS OF CONCERN AS AN IMPERATIVE FOR MANAGEMENT SCHOLARS}

The Green and the Black: The Complete Story of the Shale Revolution, the Fight Over Fracking, and the Future of Energy, by Gary Sernovitz. New York: St. Martin's Press, 2016.

Under the Surface: Fracking, Fortune, and the Fate of the Marcellus Shale, by Tom Wilber. Ithaca: Cornell University Press, 2015 (updated edition).

According to a recent Bloomberg Businessweek cover story, the United States is poised to become the largest oil producer in the world by the end of 2018 (Blas, 2018). This is a remarkable development, considering that the U.S. imported more than 12 million barrels per day as recently as a decade ago. In fact, the United States is now producing so much oil that it repealed a 40-year ban on oil exports and, by 2017, was shipping some 1.3 million barrels per day to buyers in China, India, South Korea, Venezuela, and elsewhere (Krauss, 2017). At the heart of the United States' transformation into an energy superpower is an extraction process colloquially known as “fracking." Fracked hydrocarbons, extracted mainly from seven "shale plays" (see Figure 1), have displaced oil from Saudi Arabia, Libya, Nigeria, and Venezuela and generated geopolitical ripple effects, especially for OPEC members and Russia. Domestically, this abundance has unlocked untold riches, by some estimates totaling $\$ 1.8$ to $\$ 2$ trillion in the oil and gas sector, in addition to "the wealth gained by the farmers, ranchers, government entities, and others who leased land to oil and gas companies" (Sernovitz, 2016: 123-124). This good fortune has also "trickled down" in the form of jobs. Between 2004 and 2014, oil and gas industry related employment in the U.S. grew from 450,000 to 850,000 jobs, with average pay increasing from $\$ 71,000$ to $\$ 112,000$ over the same timeframe (Sernovitz, 2016: 207). 
Given its visibility and impact, the shale revolution has been the subject of numerous books over the past several years (e.g., Gold, 2014; McGraw, 2011; Sernovitz, 2016; Wilber, 2015; Zuckerman, 2013). These books, along with media coverage, portray fracking as a major technological disruption with tremendous economic and geopolitical implications, and proportionately significant environmental and health concerns (e.g., Gehman, Thompson, Alessi, Allen, \& Goss, 2016; Mazur, 2016). But like the financial crisis (Starkey, 2015) and income inequality (Tsui, Enderle, \& Jiang, 2017), the shale revolution is also very much a management story, even though it is rarely analyzed as one. As we document below, its origins are entrepreneurial, closely adhering to the disruptive innovation paradigm (Christensen, 1997). Akin to the evolution of the electric light and power grid (Hargadon \& Douglas, 2001; Hughes, 1993), contemporary approaches to software development (O’Mahony \& Ferraro, 2007), and innovation processes in biotechnology (Owen-Smith \& Powell, 2004), it is impossible to fully comprehend the history and future trajectory of fracking if we consider it to be merely a technological or economic accomplishment.

In this review essay, we assess the shale revolution through the lens of management theory and practice. To do so, we draw on two recent books. First, based on a close reading of The Green and the Black, by Gary Sernovitz, we contend that fracking in America is a textbook example of "good" management. Nonetheless, as we subsequently document, fracking's influence extends beyond immediate impacts in many social, environmental, and economic spheres, often with negative repercussions. Indeed, at different points during the last 20 years, fracking has been at the center of considerable contention and debate. Although management scholars have remained on the sidelines, academics from a variety of other disciplines have 
actively participated in this debate. We identify several topics where management scholars seem positioned to contribute well-informed opinions on fracking.

Then we draw upon Under the Surface, by Tom Wilber, which provides an up-close depiction of two non-management scholars-Professors Terry Engelder (geosciences) and Anthony Ingraffea (civil engineering) — and their sustained efforts to further the public debate on fracking in the United States. Their dialogues suggest models of possible management engagement and inspire us to reconsider what role, if any, management scholars might play as public intellectuals engaged in debates about major societal issues. Taking these two professors as potential archetypes, we suggest that one way for management scholars to increase their relevance and influence is by taking informed, evidence based, but ultimately principled positions on issues that are of concern to society.

Fracking, like many other issues confronting the world today, is values-laden. Accordingly, it is neither necessary nor likely that management scholars will agree with each other about which concerns are worth engaging or concur on how to address them. Here our essay raises issues that go beyond simply noting the absence of management scholarship on certain topics (e.g., Starkey, 2015). Similarly, compared with the hand-wringing in our field that has focused on strategies for crossing the rigor-relevance divide (e.g., Nicolai \& Seidl, 2010) or for deploying evidence-based management (Reay, Berta, \& Kohn, 2009; Rousseau, 2012), our investigation of the fracking debate suggests that a more fulfilling, and ultimately more profound route to scholarly impact might be through deeper engagement with what are essentially unsolvable, messy problems (Ferraro, Etzion, \& Gehman, 2015).

We close the essay by posing suggestions for what such public engagement might look like. First, we consider the kinds of problems that might lend themselves to public debate. 
Second, we tackle questions related to the ground rules for such debates, in terms of potential norms. Finally, we differentiate the kinds of public debates we have in mind from other forms of academic relevance. Essentially, we advocate for "going public" as a complement to rigorous and evidence-based academic research.

\section{MODERN FRACKING: A MANAGEMENT SUCCESS STORY}

Narrowly defined, fracking is a longstanding technology used to extricate oil and natural gas from previously untapped layers of shale rock. More expansively, fracking is a big, multifaceted real-world problem implicating people and policy, riches and risks. It thus comes as no surprise that fracking is, quite literally, Hollywood material, as both drama (Promised Land, starring Matt Damon) and documentary (Gasland, an Academy Award nominee). In many written accounts, fracking is portrayed as a story of business heroics involving acumen, innovation, grit, and endurance. The Green and the Black is a book that spins this tale engagingly. As in any good oil story, bravado, salesmanship and outsized personalities figure prominently, and Sernovitz brings them to life with aplomb. But a close, managerially-informed reading of the book suggests that at the end of the day, the emergence of fracking is a story of a high-risk/high-reward strategy that has paid off handsomely, with all the trappings of other entrepreneurial success stories lauded by the business press and in the halls of the world's business schools. Below we describe organizational and strategic aspects of this story.

\section{Fracking: Breakthrough Innovation}

Many have heralded the shale revolution as a major technological breakthrough. Agreeing with this perspective, Sernovitz clarified that it was "not some new invention, like Pringles...It was more like the iPhone, in which a lot of strands of existing and newer technologies come together" (Sernovitz, 2016: 22). Notably, the shale revolution was made 
possible by improving and combining two longstanding oil and gas technologies: slickwater fracking and horizontal drilling. ${ }^{1}$ According to Sernovitz, the way in which these technologies came together perfectly fits the pattern of disruptive innovation described by Clayton Christensen (1997) in The Innovator's Dilemma. According to this work, "Entrant firms have an attacker's advantage over established firms in those innovations - generally new product architectures involving little new technology per se - that disrupt or redefine the level, rate, and direction of progress in an established technological trajectory" (Christensen, 1997: 55). Because they are focused on improving performance within established markets, incumbent firms frequently dismiss such breakthrough innovations as irrelevant, only to later be disrupted by them.

The first element of the breakthrough, slickwater fracking, can be traced back to 1866 , when "Civil War veterans dropped dynamite torpedoes down wells to fracture reservoirs" (Sernovitz, 2016: 21). Over the next century, stimulation techniques evolved to include acid, nitroglycerin, napalm, and even a few nuclear bomb experiments. The intent behind all these experiments was to devise a method to trigger the release of oil and gas deposits from the bonds that held them in place. By the 1950s, the process now known as hydraulic fracturing became the de facto standard in the industry. The technique employs large amounts of water, typically mixed with sand and multiple chemicals, injected into the well under intense pressure.

Although early iterations of fracking increased yields in "conventional" formations, they were ineffective in extremely low permeability source rock. ${ }^{2}$ In one such formation, the Barnett

\footnotetext{
${ }^{1}$ Our description is necessarily simplified. As Sernovitz (2016: 72) put it: "To keep the description of drilling and completing a modern shale well to a tolerable length, I will leave unexplained shoes, collars, kellies, whipstocks, catwalks, monkey boards, mud cakes, reamers, and dozens of other tools and sub-processes that sound straight out of wizard camp."

${ }^{2}$ Permeability is a measure of how easy it is for oil and gas molecules to travel through the pores of a rock and, by implication, how easy it is to extract them.
} 
Shale of Texas, George Mitchell, a particularly tenacious independent oilman, spent 17 years and \$250 million trying to coax hydrocarbons out of the ground with little to show for his efforts (Hinton, 2012). Finally, in 1995, Mitchell Energy attempted a "slickwater" fracking treatment, borrowing from a recipe that had been used for decades in Kansas, which required less sand and a different, cheaper mix of chemicals. This last-ditch effort, "somewhere between a Hail Mary and a hunch," was commercially successful, and became "a signal event in the history of the oil business" (Sernovitz, 2016: 23).

On its own, slickwater fracking was not sufficient to bring about the shale revolution. The second element of the breakthrough was horizontal drilling, which enables operators to follow the contours of a layer of shale, thousands of feet below the surface. As with slickwater fracking, horizontal drilling was not devised sui generis; it too evolved from early industry practices, dating to the 1930 s. By the 1970 s, the technique had become commonplace in offshore wells, allowing companies to forego the substantial costs of building new deep-sea platforms and moving their drilling rigs over the water. Applied to fracking, this innovation evolved to enable operators to extend more than 30 horizontal well bores underground up to 4 miles in different directions from a single well pad on the surface (see Figure 2).

\section{-- Insert Figure 2 Here --}

Such a recombination of technologies over a span of several decades that leads to a commercially successful configuration is a hallmark of technological change (Tushman \& Anderson, 1986). As “disruptive innovation would predict, the future disruptors' strategies rested, self-aware, on lower margin, second rate products" (Sernovitz, 2016: 133). Consistent with Christensen's (1997) model of disruptive innovation, these breakthroughs were led not by the oil and gas "majors," but by "independents"_- "second-tier caterpillars [that] morphed into 
butterflies" (Sernovitz, 2016: 140). The large, incumbent oil companies eventually came to understand that they were being undercut by small competitors employing a relatively simple technique. However, since this technique did not fit their competencies, the incumbents deemed it uninteresting and unthreatening. In hindsight of course, the recombination of slickwater fracking and horizontal drilling into a full-fledged disruption seems obvious, but it took decades to congeal, with no a priori assurance that it would succeed.

\section{Fracking: Organizational Competencies}

By 2014, the industry had transitioned "in Max Weber's terms, from the charismatic to the bureaucratic phase of the boom" (Sernovitz, 2016: 52). By this point shale gas accounted for about half of U.S. production, up from $6 \%$ in 2007. "The reigning cliché became that we were not exploring for oil or gas anymore, but, hyperbolically, 'manufacturing' it" (Sernovitz, 2016:

51). These "bureaucratic" achievements were driven by several textbook managerial competencies discernible in Sernovitz's analysis: operational efficiencies attained through learning; effective corporate political strategy; and a focus on maintaining legitimacy.

Central to the cost-effectiveness of fracking was a dogged, iterative focus on operating efficiency. In fact, the industry is extremely specialized: specific tasks in each of the thousands of wells active at a given moment in time are outsourced to service companies like Halliburton and Schlumberger, which work seamlessly alongside operators in a precisely calibrated sequence of steps. Operators excel at supply chain management, choreographing the hundreds of trucks rumbling to and from well sites carrying sophisticated technical equipment and raw materials, as other trucks remove wastes (see Figure 3). Fracking operations cost operators thousands of dollars an hour, so efficiency and speed are crucial. 
The learning that promoted these operational capabilities occurred at the levels of the individual firm, industry suppliers, and regulators (Fershee, 2012; Gehman, Mastroianni, Grant, \& Etzion, 2012; Mani \& Muthulingam, 2018). Collectively, the industry developed norms of competition that allowed each operator to appropriate "value from their own technological advances but at the same time benefit generally from advances made by others" (Golden \& Wiseman, 2015: 1006). The service companies supplying the industry "acted as natural crosspollinators of techniques and geological information as they moved from job to job and company to company" (Golden \& Wiseman, 2015: 1009-1010). As a result of these efforts, a typical well drilled in 2013 extracted 17 times as much as the average well in 2007. Not only was each new well producing more gas, it was doing so with far fewer resources. By early 2015, there were only 300 drilling rigs operating in the United States, one-sixth the number operating in the summer of 2008. Yet total U.S. production continued "to climb every year because of headturning efficiency gains" (Sernovitz, 2016: 53).

Fracking companies also prioritized corporate political strategy. Through lobbying and other channels of influence, they have carved out a regulatory niche tailored to their interests, largely by gaining exemptions from federal law (Cahoy, Gehman, \& Lei, 2013; Centner, 2013). In particular, the industry has collaborated closely with government in research and development (R\&D) through public-private partnerships, such as the Gas Research Initiative (GRI), whose members represent the three key segments of the industry_-producers, pipeline companies, and local distribution companies. Overall, relationships with governments at the local, state, and federal levels in this regulated industry have been excellent. As Sernovitz noted, "there has never been a day when [shale development] felt at risk of being derailed by politics in the most prolific areas" (Sernovitz, 2016: 203). 
Finally, the industry takes pains to nurture and maintain its legitimacy, a particularly important task for an activity at risk of stigmatization. Fracking companies employ discursive strategies to "idealize natural gas as the perfect bridge fuel" (Finewood \& Stroup, 2012: 74) by emphasizing its low carbon emissions, domestic origins, and positive impacts on local economic development. The industry often employs a neoliberal frame, arguing that in properly functioning energy markets, consumer desires and local concerns are effectively transmitted through price signals, rendering regulations redundant. Such frames may resonate with rural, self-reliant communities that emphasize individual property and property rights (Kriesky, Goldstein, Zell, \& Beach, 2013), even though residents in some regions remain skeptical (Theodori, Luloff, Willits, \& Burnett, 2014). Like many other extractive industries, fracking companies are almost obsessively committed to worker safety. "Almost every board meeting of every company in the oil business starts with a review of HS\&E [health, safety, and environmental] incidents, even if it's just an oilfield worker getting a scrape on his hand." (Sernovitz, 2016: 108). Overall, fracking companies employ discursive and operational strategies to maintain positive reputations with local stakeholders, thereby ensuring they retain their social licenses to operate (Gehman, Lefsrud, \& Fast, 2017).

\section{WHY ALL THE FUSS OVER FRACKING?}

From a managerial perspective, fracking appears to be a perfect example of theory informing practice, or perhaps practice corroborating theory. With pluck and determination, entrepreneurial oil companies disrupted a stagnant, hegemonic industry, unleashing innovation to produce a much-needed product and create vast amounts of wealth. In doing so, they studiously deployed political strategies, successfully maintained organizational legitimacy, and learned incessantly. At first glance, it seems that management scholars should be lauding their efforts as 
a success story; yet, this is not the case. To understand why, we must first understand why there has been so much contention around fracking.

Fracking caught many by surprise, not just professionals in the energy sector, but also rural communities where drilling activity was unexpected and foreign. Even though the pace of fracking increased dramatically, it remained largely under the general public's radar until 2010, when press coverage began in earnest and the documentary movie Gasland debuted (Mazur, 2016; Vasi, Walker, Johnson, \& Tan, 2015). According to Sernovitz (2016: 65), the latter remains "the most famous argument against shale drilling," vividly depicting detrimental health outcomes associated with fracking in rural communities. In the years since, the debate around fracking has come to encompass many additional concerns, including land rights, environmental justice, watershed protection, and economic disparity, to name just a few. One way to make sense of these different, yet often interrelated issues is to approach them from two perspectives. First, what happens when something goes wrong? Second, what happens if everything goes right? Whereas the first question is primarily about local consequences, the second is primarily about global costs.

\section{Local Consequences}

A long list of health and environmental harms has been attributed to fracking (e.g., US EPA, 2016). Sernovitz (2016: 9) conceded that "oil and gas drilling is loud, dirty, and complicated. Its accidents have real victims." In his opinion, Gasland is difficult to watch because it showcases "unfortunate bystanders whose lives have been rattled by what the oil business did to their water. Middle-class or poorer, they feel abandoned by the government and assaulted by a rich industry" (Sernovitz, 2016: 67). A prominent example in the documentary is Dimock, Pennsylvania, "the most notorious case of water contamination in the history of the 
boom ... illustrative of how shockingly sloppy some in the industry were in the boom's early days." (Sernovitz, 2016: 69).

Yet, for all the unnecessary pain inflicted by Cabot Oil and Gas upon the residents of Dimock, it pales in comparison with high-profile instances of organizational malfeasance and criminality in other sectors (e.g., Palmer, Smith-Crowe, \& Greenwood, 2016). After a decade of fracking tens of thousands of wells across some 20 states, ${ }^{3}$ we have witnessed no spectacular failure comparable to the scandal resulting from Enron's corporate culture (McLean \& Elkind, 2003), the accident at the Three Mile Island nuclear plant (Perrow, 2011) or NASA's organizational paralysis vis-à-vis the Challenger spacecraft (Vaughan, 1996), not to mention the Deepwater Horizon spill in the Gulf of Mexico (Hoffman \& Jennings, 2011) or the Volkswagen emissions scandal (Rhodes, 2016). Cabot, by contrast, set aside some $\$ 4$ million to settle with residents of northeastern Pennsylvania, a minor speedbump in the fracking revolution. From an academic standpoint, this could be framed as good management. Sernovitz argued that at the end of the day, the industry does not want to be sued, hampered, or slowed down by regulators and local communities; therefore, operators are constantly seeking to learn and improve their practices to minimize negative impacts. Conceding this point leads us to ask perhaps a more meaningful question: What happens when fracking is done right, particularly at scale?

\section{Global Costs}

Many long term and chronic environmental concerns remain unanswered in the fracking debate, even if no accidents occur. Compelling claims have been put forward regarding the unsustainable strain placed on watersheds when enormous amounts of water are withdrawn to be injected into wells (Alessi et al., 2017). Others point to the flowback of fracking fluid, and the

\footnotetext{
${ }^{3}$ The U.S. Energy Information Administration reported shale gas production from 20 states through 2015, and tight oil production from a dozen. See https://www.eia.gov/dnav/ng/ng_prod_shalegas_s1_a.htm and https://www.eia.gov/tools/faqs/faq.php?id=847\&t=6
} 
extent to which it can be treated adequately over the long term to prevent the migration of toxic chemicals, brine and heavy metals from the earth's crust into local water supplies. Geologists are actively debating whether injecting wastes into the ground induces seismic activity, particularly in areas with no previous history of earthquakes (Ellsworth, 2013). Additional topics include fracking's effect on air quality, noise, and indirectly, leaks and spills from the pipelines and trains that deliver fracked hydrocarbons to market.

From a global perspective, perhaps the biggest question relates to the effect of fracking on climate change. According to Sernovitz, the shale revolution has benefited the global environment, displacing 200 million tons of coal per year. Thanks to natural gas, between 2007 and 2012 U.S. carbon dioxide emissions fell "a world-leading 725 million metric tons, equivalent to the total emissions from Germany" (Sernovitz, 2016: 7). This echoes the standard trope used by the oil and gas industry: modern society is heavily dependent on abundant, uninterrupted energy, and even the staunchest environmental advocates appreciate heating and electricity. Sernovitz also contended that natural gas is the most attractive "bridge fuel" to transition away from coal into a carbon-free energy future driven by renewable resources such as wind and solar. However, this argument conveniently ignores that fracking is also an effective means for extracting oil, used almost entirely for transportation.

Others contend that the concept of a bridge fuel is illusory (e.g., Levi, 2013; McJeon et al., 2014). Managerial concepts such as sunk costs, investment horizons, and path dependencies suggest that these investments will be milked for all they are worth, especially when considering the capital-intensive pipelines and refinery infrastructure that support fracking. After all, it is hard to imagine a situation in which a hydrocarbon resource is available, inexpensive, and managed by entrenched, powerful interests, yet remains in the ground. Other detractors of 
fracking, among them prominent climate change advocate Bill McKibben, founder of 350.org, have highlighted concerns about the release of "fugitive" methane from wells; by some accounts, this short-lived but potent greenhouse gas negates the carbon mitigation advantage of natural gas over coal.

Matters of concern like fracking "provoke perplexity and thus speech in those who gather around them, discuss them, and argue over them" (Latour, 2004: 58). For example, in 2009, Robert F. Kennedy, Jr., chief attorney for the Natural Resources Defense Council and a highprofile environmentalist, wrote in a Financial Times op-ed that converting quickly from coal to gas was U.S. President Barack Obama's best strategy for saving the planet and jumpstarting the economy after the financial crisis. But, after visiting Dimock in 2010, Kennedy Jr. reversed his views on fracking by 2013. Obama, who made climate change a key theme of his presidency, resolutely supported fracking as late as 2014 when he heaped praise on the oil and gas industry in his State of the Union address: "One of the reasons why [America is approaching energy independence] is natural gas. If extracted safely, it's the bridge fuel that can power our economy with less of the carbon pollution that causes climate change."

As these statements illustrate, fracking is not only a matter of facts, but also of values. Because such concerns are value-laden, as academics we may feel that they are outside our purview. Yet, as Suddaby reminds us, in good academic work "facts and values interpenetrate and reinforce each other" (Suddaby, 2018: 3). In our view, matters of concerns such as fracking are worthy of thorough, informed scrutiny by academic researchers, precisely because they are complex, multifaceted, and evolving. Tom Wilber, in his book Under the Surface, provides an exemplar of how academics can contribute to public debate in his portrayal of two prominent natural scientists and their role in the fracking revolution. In the next section, we examine their 
positions on fracking and the lengths to which they went to shape public understanding and action on the topic.

\section{ACADEMICS IN THE PUBLIC SQUARE}

Under the Surface provides a detailed historical account of fracking in two neighboring states, Pennsylvania and New York, both overlaying the Marcellus Shale. Wilber assiduously detailed the community cultures, social movements, and political forces which led Pennsylvania to embrace fracking and become its mecca, while these same forces prompted New York to impose a moratorium and eventually ban fracking entirely. We focus on his coverage of two key actors in this history: Terry Engelder, a professor of geosciences at Pennsylvania State University in University Park, Pennsylvania, and Anthony Ingraffea, a professor of civil engineering at Cornell University in Ithaca, New York. These prominent, reputable scholars are at polar extremes on fracking. Engelder's starting point is the immense economic value of hydrocarbons that can be unlocked by fracking, and the boost these riches can provide to local communities. Ingraffea's starting point is that fracking at the scale envisioned by Engelder is harmful to the health of local communities and disastrous to earth's climate. The debate is fascinating precisely because both scholars appear to be right; both have decades of experience and ample peer-reviewed research to back up their claims.

\section{Professor Terry Engelder (Pennsylvania State University)}

In January 2008, Engelder "was among the first to assign a commercial value" (Wilber, 2015: 2) to the Marcellus shale, pegging its size at 168 to 516 trillion cubic feet of gas, an astounding figure that meant the play was classified, in industry parlance, as a supergiant. Engelder's estimate was two orders of magnitude (!) larger than the U.S. Geological Survey's estimate of 1.9 trillion cubic feet. In a Penn State University press release, Engelder was quoted 
as saying, "The value of this science could increment the net worth of U.S. energy resources by a trillion dollars, plus or minus billions" (Wilber, 2015: 97). This estimate assumed that only 50 trillion cubic feet of the gas could be recovered. After analyzing initial production data from 2009, Engelder raised his recovery estimate nearly tenfold to 489 trillion cubic feet, enough to meet U.S. natural gas demand for decades (Wilber, 2015: 97). Perhaps not surprisingly, his calculation made international news headlines, and in a cover story about shale gas, Time magazine profiled him as someone who "played a key role in the discovery of the Marcellus" (Wilber, 2015: 94).

Engelder's work was actively promoted by his university. In fact, Penn State saw an opportunity to position itself at the center of academic research on shale and gave Engelder course relief to take a more visible role in promoting fracking in particular and the university more generally. He was actively courted by oil industry executives, investors, and journalists, as well as others who saw economic opportunity in extracting hydrocarbons from the Marcellus. More than one corporation reportedly offered him a seven-figure salary. Many hung on his every word and much of the rise in lease prices starting in 2008 can reasonably be attributed to his calculation of the commercially retrievable hydrocarbons in the shale play. Similarly, a brief but very significant spike in natural gas prices occurred on the day he made his calculations public. Engelder had effectively leveraged his academic expertise and positioned himself to be an influential voice in the public discourse on fracking.

\section{Professor Anthony Ingraffea (Cornell University)}

Anthony Ingraffea joined Cornell in 1977. His specialty is rock fracturing mechanics, particularly how fractures can be induced to promote extraction. However, Ingraffea's research and experience led him to believe that "pairing the application of [horizontal drilling and 
hydrofracking] for extracting shale gas poses unacceptable risks" to local communities and the global climate (Wilber, 2015: 5). In late 2009, just as the Marcellus shale boom was getting started, Ingraffea began challenging the claim that shale gas constituted a bridge fuel from dirty coal to a cleaner, more sustainable energy future. Ingraffea "kept hearing that fracking had been done since 1947 over a million times without problems" (Wilber, 2015: 150). He regarded these and other industry claims as "inaccurate, disingenuous, and in some cases outright lies," because the Marcellus play was at an "entirely different scale" than any previous projects (Wilber, 2015: 150).

As a counterpoint to Engelder's breathless promotion of the industry, Ingraffea began giving public lectures, "using industry figures and science to show why, in his view, shale gas operations are a net social and environmental loss" (Wilber, 2015: 181). In 2010, Ingraffea gave more than 50 lectures, "filling community halls and library conference rooms in upstate New York with rapt audiences" (Wilber, 2015: 181). He argued that realizing Engelder's Marcellus estimates would result in "massive and intensive industrialization" (Wilber, 2015: 182) on the order of 8 wells per square mile. Multiplied across the entire Marcellus shale, Ingraffea calculated it would require 400,000 wells across Pennsylvania, New York, West Virginia, Ohio, and Maryland to produce the 489 trillion cubic feet Engelder promised. By 2017, Ingraffea had made 161 public appearances throughout North America, updating his presentation with new scientific findings as they emerged (personal communication, 2017).

\section{Debating Fracking}

On January 14, 2011, Terry Engelder and Tony Ingraffea held a public debate in LaPorte, Pennsylvania, a tiny hamlet about midway between Cornell and Penn State (Wilber, 2015: 217). Engelder, who was used to industry-friendly audiences, spent much of his talk explaining why 
the problems in Dimock were simply inevitable and necessary growing pains that would ultimately benefit the entire country. Alluding to John F. Kennedy's famous call to "Ask not what your country can do for you—ask what you can do for your country," Engelder reasoned: "The people in Dimock have already done that, in spades. It's their sacrifice, hopefully, that is necessary if the gas industry continues to evolve and help other people" (Wilber, 2015: 218). Like Sernovitz, Engelder saw Dimock as merely a case study in how not to frack. He argued that the industry would learn from these challenges and move forward.

Ingraffea countered, shifting the narrative from local consequences to global costs: even if industry could someday "get it right" and eliminate all leaks and spills, the global impact from burning nonrenewable energy would be a net loss (Wilber, 2015: 218). "The idea of using natural gas as a bridge fuel to some brighter sustainable energy future was a carefully crafted myth" (Wilber, 2015: 219). Ingraffea based his argument on methane emissions, a by-product of drilling. According to Ingraffea's calculations, fugitive methane emissions were more damaging to the climate than coal plants.

During this debate and in subsequent exchanges, Ingraffea and Engelder sparred on several levels. At the level of academic discourse, they disputed theories and empirical findings, as is appropriate in scientific endeavors as we learn more, conduct additional analyses, and deepen our theoretical understandings. But Engelder and Ingraffea were influential because the implications they drew were practically consequential. They excelled at using their professional knowledge and building upon it to address bigger questions. Although both scholars focused on fracking, Engelder drew on his expert knowledge of geological deposits to highlight economic opportunities, whereas Ingraffea drew on expert knowledge about the migration of chemicals through geologic strata to highlight health and climate implications. Using facts and bona fide 
scientific findings, they unabashedly attempted to shape the debate about an important issue with long-term societal implications. They did this in person and through scholarly outlets, for example in Nature (Howarth, Ingraffea, \& Engelder, 2011), engaging directly with each other's arguments. Both men knew their facts, but more importantly they showed up in public venues, and they risk being booed off the stage, caricatured, or vilified.

\section{What Is Being Debated?}

Importantly, the Engelder-Ingraffea debate was explicitly values-laden. Engelder, for example, emphasized that fracking was a means for the United States to attain energy independence, and to create economic opportunities for rural communities. His position, therefore was one that emphasized national security and financial gains. Ingraffea, in contrast, highlighted impacts on human health, local ecosystems, and climate change. He believed the risks of fracking were too high; Engelder believed that fracking was too valuable to be suppressed (Engelder, 2009; Howarth et al., 2011; Ingraffea, Wells, Santoro, \& Shonkoff, 2014). At a fundamental level, underlying the academic jargon, and undeniably informing the research they conduct, are ideology and values.

Such dynamics are endemic to matters of concern: "They do not conceal the researchers who are in the process of fabricating them, the laboratories necessary for their production, the instruments that insure their validation, the sometimes heated polemics to which they give risein short, everything that makes it possible to articulate propositions" (Latour, 2004: 87-88). Many management researchers, it seems, experience uneasiness when their research veers into terrain that is imbued with such values-laden implications. Often, we prefer to imagine that our research is value neutral. An implicit assumption in our field is that management practices informed by academic research are desirable and should be implemented by organizations. Much 
of our research identifies opportunities to minimize wasted time, effort and resources, spur innovation, or make workplaces vibrant and welcoming. Positive, "instrumental" research outputs like these can be widely adopted (Kieser, Nicolai, \& Seidl, 2015)—whether by fracking companies or others. We cannot assume, however, that all of our research endeavors will fall into this category. To wit, in the context of fracking, recommendations for practitioners about how to manage effectively will not tell them whether or not fracking is the right thing to do.

Management theory can inform practitioners how to frack and how to frack better, but not whether they should frack at all, and if so, whether it is more preferable in some circumstances than others.

In values-laden research contexts such as fracking, it may well be impossible to avoid expressing an ideological disposition. This may make management scholars uncomfortable, and it might seem at first glance that relinquishing a detached, clinical posture when engaging in research and debate about societal issues is risky and awkward. We suggest, however, that debates about values-laden topics also have the potential to be generative, prompting us to do thorough research that contributes to forming a consequential, though not cohesive picture. In the case of fracking, geologists, energy economists, climate change scientists, public health researchers, and social scientists all have written copiously on fracking and its consequences. Their analyses, all passing the muster of peer-review, do not lead to the same prescriptions about whether fracking is good or bad, and therefore whether it should be promoted or prohibited.

Substantive, engaged, ongoing contention is not at all undesirable. The thrust and parry of debate informed by new studies casts additional light on known issues. It also has the potential to identify new issues or ameliorate others. There simply may not be one right answer to the question of fracking, but the trope "more research is needed" is manifestly true, especially when 
it is coupled with the presentation of findings to public audiences. There may not be closure, no accumulation of evidence to point the way (Reay et al., 2009; Rousseau, 2012), but this lack of convergence need not be a deterrent (Sarewitz, 2004). This is likely to be the case for a great many concerns facing the world (Chandler, 2014; Latour, 2004). And it is precisely such matters of concern that need deliberation.

\section{ENTERING THE FRAY}

Engaging in public debate might serve as a palliative for the somewhat tortured tradition of soul-searching about the real world importance of management research. Often, our challenge as a field is framed as making rigorous research relevant for audiences who can benefit from the knowledge we accumulate. Complementarily, we suggest that sometimes relevance may be a matter of showing up_engaging with big, important, real world issues and participating in devising thoughtful, meaningful ways to deal with them. Below we sketch out the contours of what such participation might entail.

In general, it is likely that public debate about matters of concern will center on issues, not theories. For instance, contention around fracking, both in public discourse and in the academic arena is not driven by theory. Instead, it is driven by phenomena, such as pollution and pipelines, and their real world consequences. Sometimes, theories will be laid out in making an argument, but typically the nuances and specificities remain taken for granted (e.g., Green, Li, \& Nohria, 2009). Extension of theory or development of new theoretical insights is not a goal in and of itself. Such an emphasis is currently very much at odds with how academic success is attained in the Academy. Typically, we imagine that our theories and the studies we conduct are broadly generalizable, and that context has very little importance for creating knowledge that is 
valid and transferable. This also creates and sustains paradigm-based communities, cohering around theoretical concepts, but not around phenomena.

These norms are not often conducive to engaging in public debate. Public debate is more likely to center on issues such as the gig economy or gender inequality, not the intricacies of institutional theory or the Carnegie school. This suggests that a certain ambidexterity is required, a mastery of both context and theory. Effectiveness in public discourse entails familiarity with work on the same issue in other academic disciplines, and an understanding of the theoretical underpinnings of those complementary streams of research. It is likely to also require greater empirical familiarity with the context, such as in situ immersion and non-academic discourse.

When debating, researchers should express themselves in more than one register - both in the specialized language of academics, in journals, and in vernacular language in other venues. Social media and the Internet allow researchers to write blogs, record podcasts and respond to current events quickly and concisely, and faculty are increasingly encouraged to take on this form of public engagement (e.g., Stein \& Daniels, 2017). These media can help those of us who desire to do so to engage with academics from other disciplines and even non-academic audiences, particularly about current events and how our research can help make sense of them. Online media (e.g., The Conversation, Pacific Standard), that have been established recently with the express purpose of showcasing important research findings also provide excellent platforms for highlighting how our research informs recommendations about appropriate choices for society (e.g., Delmas \& Lyon, 2018). Our own academic journals may aspire to host debates centered on contemporary matters of concern (and not just theoretical ones), in much the same way that Nature hosted dueling articles from Engelder and Ingraffea in a debate titled simply: "Natural gas: Should fracking stop?" 
A challenge with debate of any type is that it can spiral out of control, particularly when values are explicitly stated. Opposing points of view can be caricatured, rather than carefully dissected. Hidden agendas can be insinuated, and ad hominem attacks can displace commentary over facts and logic. As a field, we seem able to avoid these traps in our intra-disciplinary academic debates (e.g., see the spirited exchange between Steve Kapan and Jim Walsh over the fairness of CEO compensation; Kaplan, 2008a, 2008b; Walsh, 2008, 2009). When engaging with other audiences, we cannot be sure of the same success. One guideline might be to express ideological starting points and deeply-held beliefs clearly, to avoid audiences making assumptions. Presenting the biographical history and personal journey that has informed one's position may be another key to helping audiences understand the values commitments that inform one's work. Another rule of thumb could be to delineate as carefully as possible what is a research finding versus what is a belief statement, perhaps further distinguishing well-established findings from those that are emergent or tenuous.

\section{CONCLUSION: FACTS DON'T SPEAK FOR THEMSELVES}

In our view disagreement on values-laden issues of concern is not a flaw to be glossed over, but rather an important feature that should be nurtured. According to political philosopher Michael Sandel (2012): “Our reluctance to bring competing conceptions of the good life into political debate has ... impoverished our public discourse.” If we are reticent in conducting research and presenting it in a transparent way that makes our values known, then we are likely to abstain from speaking out about societally consequential issues.

This would be unfortunate because management scholars are quite well positioned to participate. As scholars, we analyze phenomena at micro, meso, and macro scales using a dizzying variety of research methodologies that enable us to understand complex, nuanced issues 
from multiple perspectives. Our research interfaces with economics, sociology, policy, and psychology, to name but a few disciplines, meaning we can credibly apply concepts such as entrepreneurial opportunity, regulatory capture, social movements, shareholder value, and stakeholder rights to pertinent issues. Many of us engage with organizational leaders through consulting and executive education, and these opportunities have enabled us to hone our communication skills for non-academic audiences. When engaging with our students, we often rely on case studies, many of which provide information about contemporary societal issues and are, quite literally, designed to encourage debate. Overall, it seems we do not lack in training, credentials, or opportunities to make meaningful contributions to public discourse. For these reasons and more, we believe the time has come for management scholars to go public. 


\section{REFERENCES}

Alessi, D. S., Zolfaghari, A., Kletke, S., Gehman, J., Allen, D. M., et al. 2017. Comparative analysis of hydraulic fracturing wastewater practices in unconventional shale development: Water sourcing, treatment and disposal practices. Canadian Water Resources Journal, 42(2): 105-121.

Blas, J. 2018, January 29. The new world order of energy will be American. Bloomberg Businessweek, (4556): 10-12.

Cahoy, D. R., Gehman, J., \& Lei, Z. 2013. Fracking patents: the emergence of patents as information containment tools in shale drilling. Michigan Telecommunications and Technology Law Review, 19: 279-330.

Centner, T. J. 2013. Oversight of shale gas production in the United States and the disclosure of toxic substances. Resources Policy, 38(3): 233-240.

Chandler, D. 2014. Morals, Markets, and Values-Based Businesses. Academy of Management Review, 39(3): 396-406.

Christensen, C. M. 1997. The Innovator's Dilemma: When New Technologies Cause Great Firms to Fail. Boston: Harvard Business School Press.

Delmas, M., \& Lyon, T. 2018, July 17. When corporations take credit for green deeds their lobbying may tell another story. The Conversation. http://theconversation.com/whencorporations-take-credit-for-green-deeds-their-lobbying-may-tell-another-story-98988.

EIA. 2018. Drilling Productivity Report. Washington, DC: US Department of Energy. http://www.eia.gov/petroleum/drilling/pdf/dpr-full.pdf.

Ellsworth, W. L. 2013. Injection-Induced Earthquakes. Science, 341(6142): 1225942. 
Engelder, T. 2009. Marcellus 2008: Report card on the breakout year for gas production in the Appalachian Basin. Fort Worth Basin Oil \& Gas.

Ferraro, F., Etzion, D., \& Gehman, J. 2015. Tackling grand challenges pragmatically: Robust action revisited. Organization Studies, 36: 363-390.

Fershee, J. P. 2012. Oil and Gas Evolution: Learning from the Hydraulic Fracturing Experiences in North Dakota and West Virginia, The. Texas Wesleyan Law Review, 19(1): 23-36.

Finewood, M. H., \& Stroup, L. J. 2012. Fracking and the neoliberalization of the hydro-social cycle in Pennsylvania's Marcellus Shale. Journal of Contemporary Water Research \& Education, 147(1): 72-79.

Gehman, J., Lefsrud, L. M., \& Fast, S. 2017. Social license to operate: Legitimacy by another name? Canadian Public Administration, 60(2): 293-317.

Gehman, J., Mastroianni, D., Grant, A., \& Etzion, D. 2012. An Analysis of Unconventional Gas Well Reporting under Pennsylvania's Act 13 of 2012. Environmental Practice, 14: 262277.

Gehman, J., Thompson, D. Y., Alessi, D. S., Allen, D. M., \& Goss, G. G. 2016. Comparative Analysis of Hydraulic Fracturing Wastewater Practices in Unconventional Shale Development: Newspaper Coverage of Stakeholder Concerns and Social License to Operate. Sustainability, 8: 912.

Gold, R. 2014. The Boom: How Fracking Ignited the American Energy Revolution and Changed the World. New York: Simon \& Schuster.

Golden, J. M., \& Wiseman, H. J. 2015. The fracking revolution: shale gas as a case study in innovation policy. Emory Law Journal, 65: 955-1040. 
Green, S. E., Li, Y., \& Nohria, N. 2009. Suspended in self-spun webs of significance: A rhetorical model of institutionalization and institutionally embedded agency. Academy of Management Journal, 52: 11-36.

Hargadon, A. B., \& Douglas, Y. 2001. When innovations meet institutions: Edison and the design of the electric light. Administrative Science Quarterly, 46: 476-501.

Hinton, D. D. 2012. The seventeen-year overnight wonder: George Mitchell and unlocking the Barnett Shale. Journal of American History, 99: 229-235.

Hoffman, A. J., \& Jennings, P. D. 2011. The BP Oil Spill as a Cultural Anomaly? Institutional Context, Conflict, and Change. Journal of Management Inquiry, 20(2): 100-112.

Howarth, R. W., Ingraffea, A., \& Engelder, T. 2011. Natural gas: Should fracking stop? Nature, 477: $271-275$.

Hughes, T. P. 1993. Networks of power: Electrification in Western society, 1880-1930. Baltimore: Johns Hopkins University Press.

Ingraffea, A. R., Wells, M. T., Santoro, R. L., \& Shonkoff, S. B. C. 2014. Assessment and risk analysis of casing and cement impairment in oil and gas wells in Pennsylvania, 20002012. Proceedings of the National Academy of Sciences, 111(30): 10955-10960.

Kaplan, S. N. 2008a. Are U.S. CEOs Overpaid? Academy of Management Perspectives, 22(2): $5-20$.

Kaplan, S. N. 2008b. Are U.S. CEOs Overpaid? A Response to Bogle and Walsh. Academy of Management Perspectives, 22(3): 28-34.

Kieser, A., Nicolai, A., \& Seidl, D. 2015. The Practical Relevance of Management Research: Turning the Debate on Relevance into a Rigorous Scientific Research Program. Academy of Management Annals, 9: 143-233. 
Krauss, C. 2017, July 6. U.S. oil exports, once banned, are now a boon. New York Times, A1.

Kriesky, J., Goldstein, B. D., Zell, K., \& Beach, S. 2013. Differing opinions about natural gas drilling in two adjacent counties with different levels of drilling activity. Energy Policy, 58: $228-236$.

Latour, B. 2004. Politics of nature. Cambridge: Harvard University Press.

Levi, M. 2013. Climate consequences of natural gas as a bridge fuel. Climatic Change, 118(34): 609-623.

Litvak, A. 2018, January 15. These days, oil and gas companies are super-sizing their well pads. Pittsburgh Post-Gazette.

Mani, V., \& Muthulingam, S. 2018. Does Learning from Inspections Affect Environmental Performance? Evidence from Unconventional Well Development in Pennsylvania. Manufacturing \& Service Operations Management. https://doi.org/10.1287/msom.2017.0695.

Mazur, A. 2016. How did the fracking controversy emerge in the period 2010-2012? Public Understanding of Science, 25(2): 207-222.

McGraw, S. 2011. The end of country: dispatches from the frack zone. New York: Random House.

McJeon, H., Edmonds, J., Bauer, N., Clarke, L., Fisher, B., et al. 2014. Limited impact on decadal-scale climate change from increased use of natural gas. Nature, 514(7523): 482 485.

McLean, B., \& Elkind, P. 2003. Smartest guys in the room: The amazing rise and scandalous fall of Enron. New York: Portfolio. 
Nicolai, A., \& Seidl, D. 2010. That's Relevant! Different Forms of Practical Relevance in Management Science. Organization Studies, 31(9-10): 1257-1285.

O’Mahony, S., \& Ferraro, F. 2007. The Emergence of Governance in an Open Source Community. Academy of Management Journal, 50(5): 1079-1106.

Owen-Smith, J., \& Powell, W. W. 2004. Knowledge Networks as Channels and Conduits: The Effects of Spillovers in the Boston Biotechnology Community. Organization Science, 15(1): 5-21.

Palmer, D., Smith-Crowe, K., \& Greenwood, R. (Eds.). 2016. Organizational Wrongdoing: Key Perspectives and New Directions. New York: Cambridge University Press.

Perrow, C. 2011. Normal Accidents: Living with High Risk Technologies. Princeton University Press.

Reay, T., Berta, W., \& Kohn, M. K. 2009. What's the evidence on evidence-based management? Academy of Management Perspectives, 23(4): 5-18.

Rhodes, C. 2016. Democratic business ethics: Volkswagen's emissions scandal and the disruption of corporate sovereignty. Organization Studies, 37(10): 1501-1518.

Rousseau, D. M. (Ed.). 2012. The Oxford handbook of evidence-based management. New York: Oxford University Press.

Sandel, M. J. 2012, June. Keeping markets in their place. Boston Review, 37(3). http://bostonreview.net/archives/BR37.3/ndf_michael_j_sandel_replies_markets_morals. php.

Sarewitz, D. 2004. How Science Makes Environmental Controversies Worse. Environmental Science \& Policy, 7: 385-403. 
Sernovitz, G. 2016. The Green and the Black: The Complete Story of the Shale Revolution, the Fight over Fracking, and the Future of Energy. New York, NY: St. Martin's Press.

Starkey, K. 2015. The strange absence of management during the current financial crisis. Academy of Management Review, 40(4): 652-663.

Stein, A., \& Daniels, J. 2017. Going Public: A Guide for Social Scientists (1 edition). Chicago: University of Chicago Press.

Suddaby, R. 2018. Objectivity and Truth: The Role of the Essay in Management Scholarship. Journal of Management Studies, In press.

Theodori, G. L., Luloff, A. E., Willits, F. K., \& Burnett, D. B. 2014. Hydraulic fracturing and the management, disposal, and reuse of frac flowback waters: Views from the public in the Marcellus Shale. Energy Research \& Social Science, 2: 66-74.

Tsui, A. S., Enderle, G., \& Jiang, K. 2017. Income Inequality in the United States: Reflections on the Role of Corporations. Academy of Management Review, 43(1): 156-168.

US EPA. 2016. Hydraulic Fracturing for Oil and Gas: Impacts from the Hydraulic Fracturing Water Cycle on Drinking Water Resources in the United States (Final Report). no. EPA/600/R-16/236F, Washington, DC: U.S. Environmental Protection Agency.

Vasi, I. B., Walker, E. T., Johnson, J. S., \& Tan, H. F. 2015. “No Fracking Way!” Documentary Film, Discursive Opportunity, and Local Opposition against Hydraulic Fracturing in the United States, 2010 to 2013. American Sociological Review, 80(5): 934-959.

Vaughan, D. 1996. The Challenger launch decision: Risky technology, culture, and deviance at NASA. Chicago: University of Chicago Press.

Walsh, J. P. 2008. CEO Compensation and the Responsibilities of the Business Scholar to Society. Academy of Management Perspectives, 22(2): 26-33. 
Walsh, J. P. 2009. Are U.S. CEOs Overpaid? A Partial Response to Kaplan. Academy of Management Perspectives, 23(1): 73-75.

Wilber, T. E. 2015. Under the surface: Fracking, fortunes, and the fate of the Marcellus Shale (Updated with a new chapter). Cornell University Press.

Zuckerman, G. 2013. The frackers: the outrageous inside story of the new billionaire wildcatters. New York: Portfolio. 


\section{FIGURE 1. THE SEVEN MAJOR SHALE REGIONS IN THE UNITED STATES}

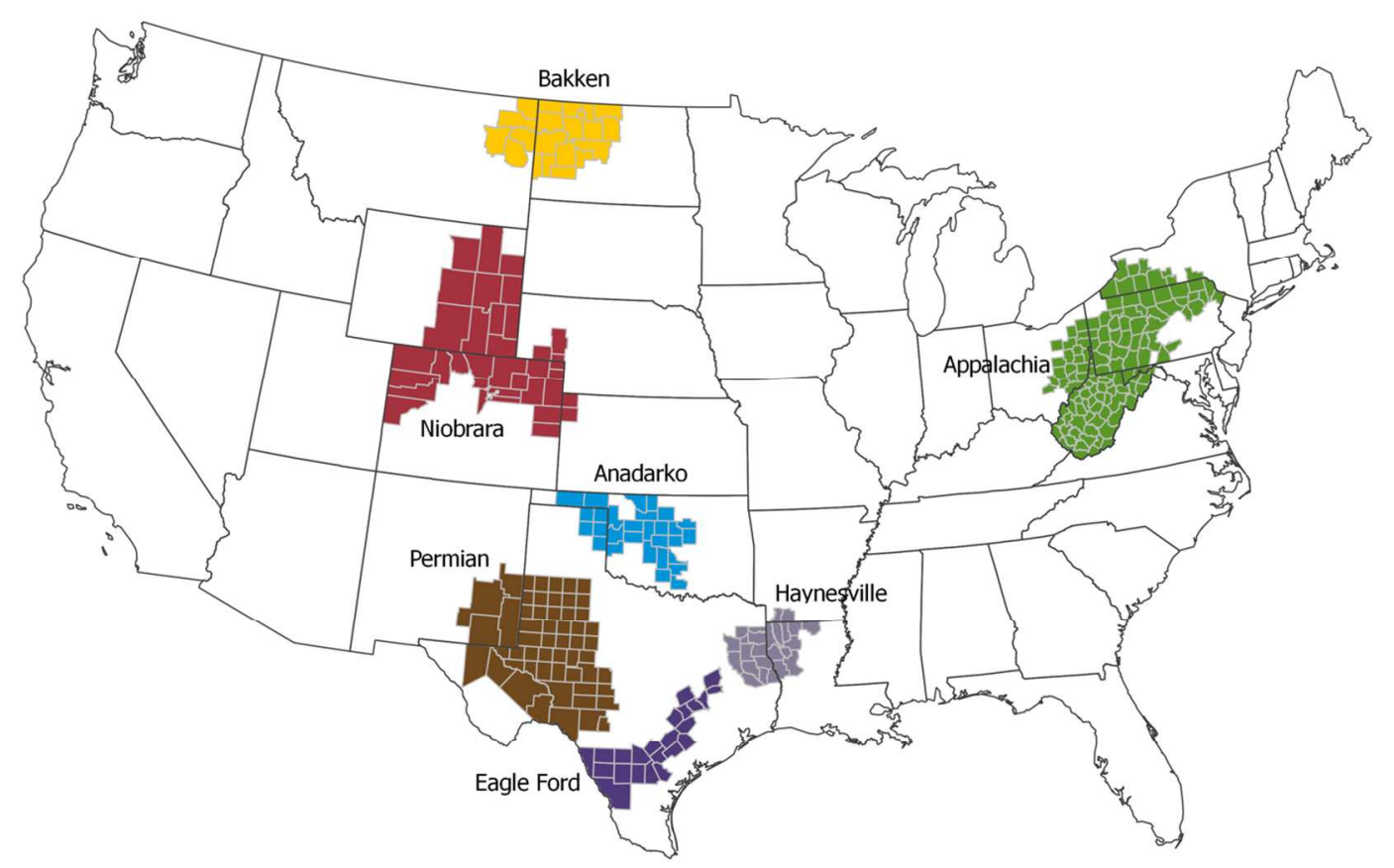

Note: The Marcellus shale is within the Appalachia basin. The Barnett shale is smaller and lies in northern Texas, south of the Anadarko basin.

Source: EIA (2018). 


\section{FIGURE 2. EQT CORP'S COGAR WELLPAD}

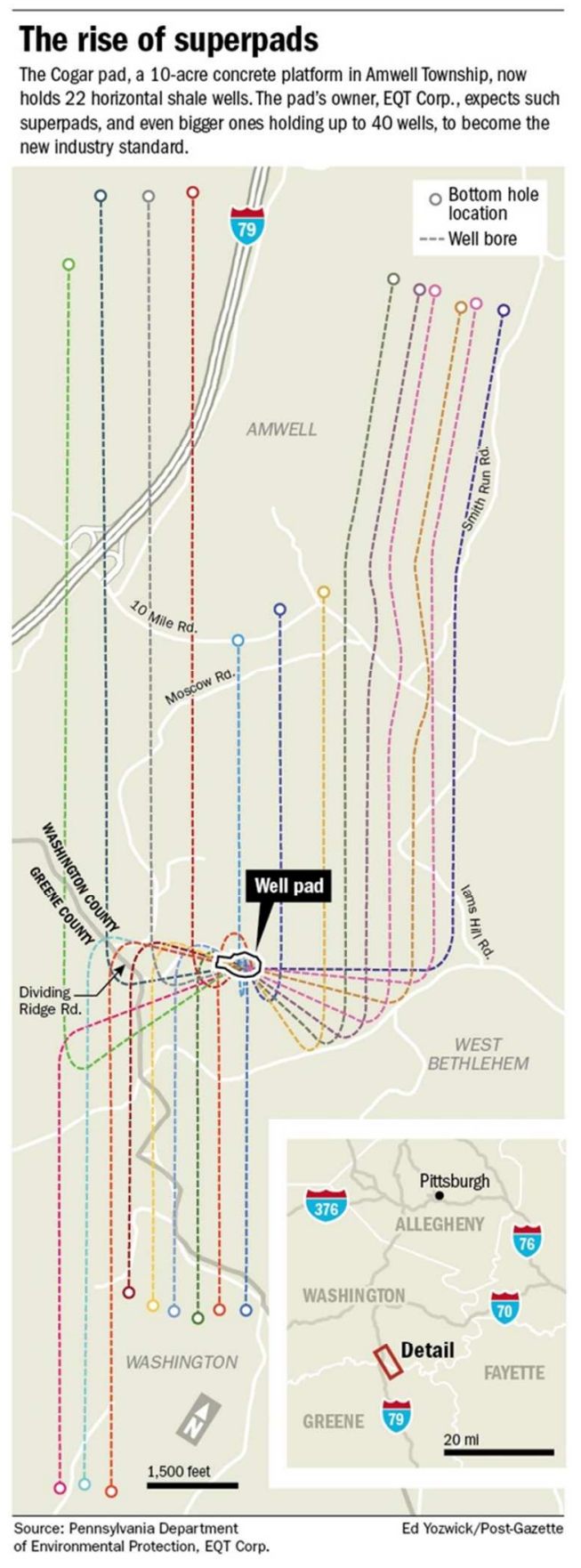

Source: Litvak (2018).

Copyright (C 2018, Pittsburgh Post-Gazette, all rights reserved. Reprinted with permission. 


\section{FIGURE 3. SURFACE OPERATIONS AT A FRACKING WELLPAD}

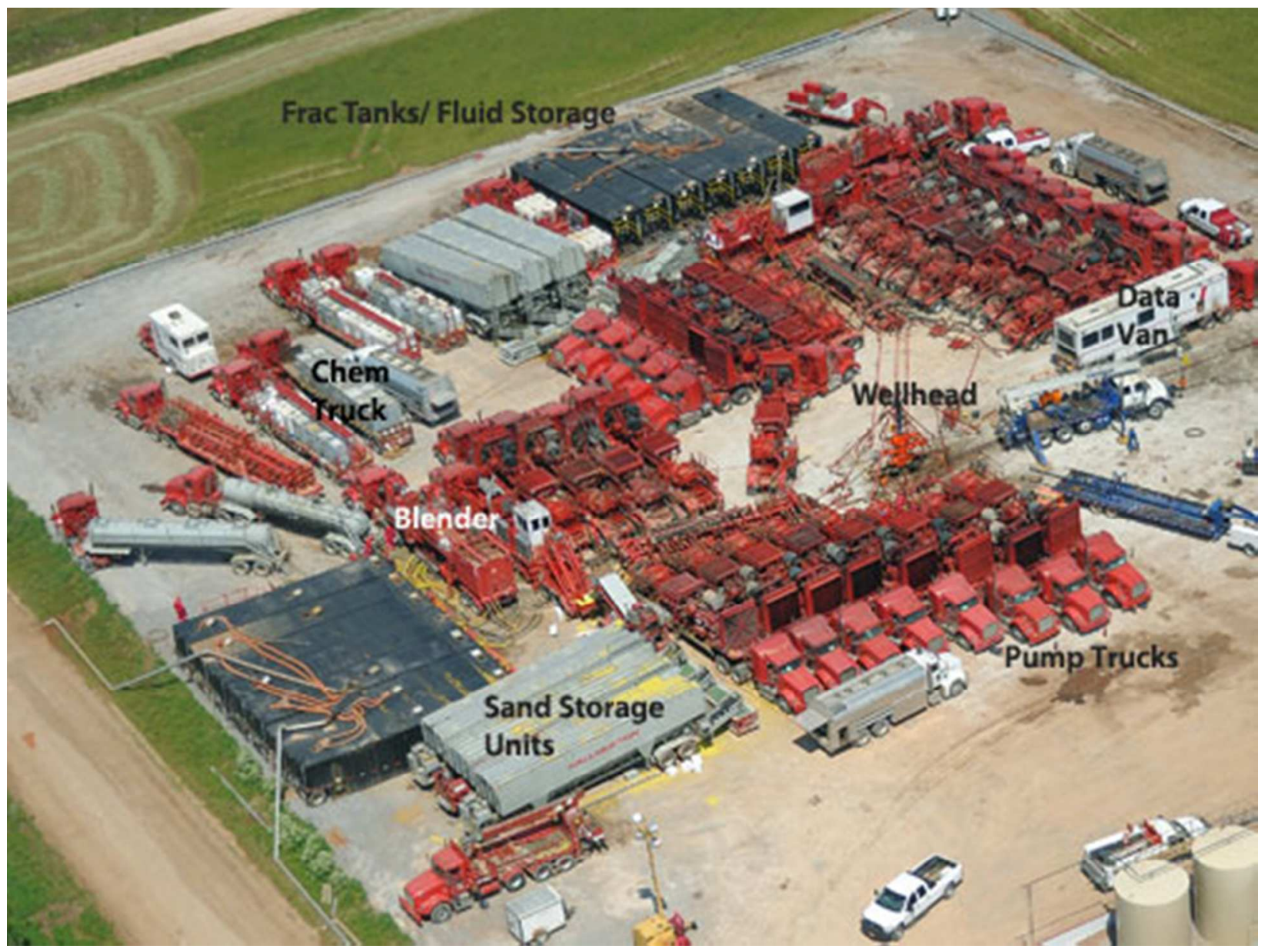

Source: http://fracfocus.org/hydraulic-fracturing-how-it-works/site-setup

Reprinted with permission. 


\begin{abstract}
About the Authors
Dror Etzion (마.etzion@mcgill.ca) is associate professor of strategy and organization at the Desautels Faculty of Management, McGill University and an associate member of the McGill School of Environment. He is currently studying the application of robust action strategies in sustainability contexts.
\end{abstract}

Joel Gehman (jgehman@ualberta.ca) is the Francis Winspear Associate Professor of Business at the Alberta School of Business, University of Alberta. His current research examines organizational responses to sustainability and values concerns, especially the role of innovation processes and cultural entrepreneurship. 